\title{
Upaya Peningkatan Keterampilan Berbicara dan Hasil Belajar Melalui Model Pembelajaran Cooperative Learning Tipe Jigsaw
}

\author{
Eva Nahgiyah ${ }^{1 *}$, Stefanus C. Relmasira ${ }^{2}$ \\ 1,2 Program Studi Pendidikan Guru Sekolah Dasar, Fakultas Keguruan Dan Ilmu Pendidikan, Universitas Kristen Satya Wacana, Salatiga
}

\section{A R T I C L E I N F O}

Article history:

Received 20 May 2019

Received in revised form 10 June 2019

Accepted 30 July 2019

Available online 28

August 2019

Kata Kunci:

Keterampilan berbicara,

Hasil belajar, Cooperative

Learning Tipe Jigsaw

Keywords:

Speaking Skills, Result of

Learning, Cooperative

Learning type Jigsaw.

\begin{abstract}
A B S T R A K
Penelitian ini bertujuan untuk meningkatkan kemampuan keterampilan berbicara dan hasil belajar peserta didik melalui model pembelajaran Cooperative Learning Tipe Jigsaw, pada mata pelajaran tematik tema 6 "Cita-citaku" pada kelas IV semester II. Penelitian ini merupakan penelitian tindakan kelas dengan menggunakan pendekatan kualitatif dan kuantitatif. Data penelitian diperoleh melalui wawancara, non tes (observasi), tes, dan studi dokumen. Subjek penelitian adalah peserta didik kelas IV SD Negeri Noborejo 01 Kecamatan Argomulyo Kota Salatiga sebanyak 34 peserta didik. Prosedur kegiatan meliputi empat tahapan yaitu perencanaan, pelaksanaan, observasi, refleksi melalui dua siklus pembelajaran, terdapat refleksi pada tindakan siklus I kemudian dilakukan perbaikan pada tindakan siklus II, setiap siklus terdiri dari 3 pertemuan. Pada siklus I persentase keterampilan berbicara peserta didik $70 \%$, kemudian meningkat menjadi $80 \%$ pada siklus II. Peningkatan keterampilan berbicara peserta didik juga berdampak pada hasil belajar peserta didik, dimana siklus I jumlah ketercapaian hanya $71 \%$ dari jumlah peserta didik meningkat menjadi $87 \%$ pada siklus II. Hasil penelitian menunjukan bahwa dengan penerapan langkah-langkah model pembelajaran Cooperative Learning Tipe Jigsaw dapat meningkatkan keterampilan berbicara dan hasil belajar pada pembelajaran tematik tema 6 "Cita-citaku" peserta didik kelas IV SD Negeri Noborejo 01.
\end{abstract}

A B S T R A C T

The study aims to improve students'speaking skills and the result of students learning through Cooperative Learning Type Jigsaw, especially fourth grade of students. The study focused on thematic subject, theme 6 entitled "Cita-citaku". The research used both method, qualitative and quantitative. Then the data was got by interview, observation and documentation. Moreover, the participants were one 34 students. There are 4 procedures to get the data from the research; (1) Planning, (2) Implementation and (3) Observation (4) The reflection also used to the research since to add accuracy of the research. The reflection passed through two cycle of learning,

There are reflections the actions in cycle I then improvements are made to the actions the second in cycle II, each cyle consist of three meetings. In the first cycle the percentage of students' speaking skills was $70 \%$, then increased to $80 \%$ in cycle II. Increasing students' speaking skills also has an impact on student learning outcomes, where the first cycle of the number of achievements is only $71 \%$ of the number of students increased to $87 \%$ in the second cycle. The results showed that the application of the steps of the Cooperative Learning type Jigsaw model can improve speaking skills and learning outcomes in hot theme 6 entitled "Cita-citaku" transfer of students to SD Negeri Noborejo 01. 


\section{Pendahuluan}

Pendidikan sekolah dasar merupakan lembaga pendidikan yang menyelenggarakan program pendidikan enam tahun bagi anak-anak usia 7-12 tahun. Sekolah dasar merupakan jenjang pendidikan yang paling dasar untuk memberikan bekal kemampuan dasar kepada peserta didik berupa pengetahuan, keterampilan, dan sikap yang bermanfaat bagi dirinya yang sesuai dengan tingkat perkembangannya. Pendidikan sekolah dasar memiliki peranan penting dalam mengembangkan aspek fisik, intelektual, religius, moral, sosial, emosi, pengetahuan, dan pengalaman peserta didik.

Menurut Anwar (2014:22) pengaruh pendidikan dalam diri seseorang merupakan pendorong kemampuan untuk berkembang. Sedangkan pendorong utamanya adalah potensi dari peserta didik berupa bakat dan pengalaman yang ada dalam dirinya. Di dalam pendidikan pasti akan ada proses belajar dan hasil belajar, proses belajar dapat melalui kegiatan belajar mengajar. Sedangkan hasil belajar merupakan hasil dari proses pembelajaran dan dari potensi peserta didik. Untuk mendapatkan hasil belajar yang baik maka diperlukan proses belajar yang baik serta tepat. Guru sebagai penanggung jawab proses belajar dikelas selayaknya memberikan pengalaman belajar yang baik dan tepat bagi peserta didik.

Berdasarkan hasil wawancara dengan guru kelas IV di SD Negeri Noborejo 01, Kecamatan Argomulyo, Kota Salatiga, Jawa Tengah peserta didik kurang dalam keterampilan berbicara, untuk menjawab pertanyaan dari guru, peserta didik hanya menjawab bila ditunjuk. Pada saat guru memberikan pertanyaan yang sudah diberikan sebelumnya, salah satu peserta didik tidak bisa menjawab, padahal ini pertanyaan yang sama.

Berdasarkan hasil observasi di kelas IV SD Negeri Noborejo 01 pada tanggal 17 September 2018, proses belajar mengajar di kelas masih bersifat teacher centered karena metode yang digunakan belum bervariasi. Guru masih menggunakan metode ceramah sehingga peserta didik kurang mendapatkan kesempatan untuk aktif mencari tahu ataupun bertukar pikiran dengan teman sekelasnya. Ketika menyampaikan materi pelajaran, sebenarnya guru sudah menggunakan lingkungan sebagai sumber belajar, namun pemanfaatan itu hanya sebatas untuk memberikan contoh kepada peserta didik. Guru menjelaskan pokok-pokok materi dengan tanya jawab dengan peseta didik, lalu guru memberikan soal sebagai evaluasi peserta didik. Dengan model ini, pembelajaran dikelas dirasa kurang menarik perhatian peserta didik dalam proses pembelajaran dan untuk konsep-konsep materi yang abstrak belum dapat divisualisasikan secara maksimal.

Dari hasil pengamatan secara keseluruhan peserta didik kurang dalam keterampilan berbicara, untuk menjawab pertanyaan dari guru, peserta didik hanya menjawab bila ditunjuk. Hanya satu atau dua peserta didik saja yang menjawab, itupun peserta didik yang sama. Peserta didik seringkali menolak apabila diminta untuk berbicara di depan teman-temannya atau di depan kelas. Hal ini terjadi karena peserta didik kurang berlatih untuk berbicara di depan kelas. Peserta didik takut akan ditertawakan oleh teman-temannya apabila membuat kesalahan saat berbicara di depan. Jika permasalahan tersebut tidak diatasi, maka akan berdampak bagi hasil belajar peserta didik.

Pada prinsipnya model pembelajaran kooperatif bertujuan mengembangkan tingkah laku kooperatif antar peserta didik sekaligus membantu peserta didik dalam pelajaran akademisnya. Dari hasil pengamatan pada kelas IV SD Negeri Noborejo 01 terlihat guru belum menggunakan model pembelajaran tertentu. Data hasil belajar peserta didik dapat dikatakan kurang maksimal karena masih ada peserta didik yang mendapatkan nilai dibawah KKM. Dari hasil studi dokumen nilai tes ulangan tengah semester terdapat 12 dari 34 peserta didik yang mendapat nilai di bawah KKM yaitu dibawah 70 dengan rata-rata nilai 67 untuk muatan pelajaran Bahasa Indonesia dan IPS.

Alternatif dari masalah ini, guru dapat menggunakan model kooperatif tipe jigsaw untuk meningkatkan keterampilan berbicara dan hasil belajar dimana pembelajaran dilaksanakan secara kelompok mandiri. Jadi peserta didik akan lebih tertarik serta fokus pada pembelajaran karena setiap peserta didik diwajibkan bertanggung jawab pada tugas yang diberikan. Melalui model pembelajaran Kooperatif Tipe Jigsaw peserta didik dapat mengemukakan pemikirannya, saling bertukar pendapat, dan saling bekerja sama. Hal ini dapat meningkatkan motivasi peserta didik untuk mempelajari dan menguasai materi pelajaran sehingga nantinya akan meningkatkan hasil belajar peserta didik. Menurut Slavin (Rusman, 2010:201) pembelajaran kooperatif menggalakakkan peserta didik berinteraksi secara aktif dan positif dalam kelompok. Ini membolehkan pertukaran ide dan pemeriksaan ide sendiri dalam suasana yang tidak terancam. Hal itu sesuai dengan pendapat dari Ahmad Susanto (2014:243) yang mengatakan bahwa pembelajaran kooperatif tipe Jigsaw adalah suatu model pembelajaran yang didasarkan pada struktur multifungsi kelompok belajar yang dapat digunakan pada semua pokok bahasan dan semua tingkatan untuk mengembangkan keahlian dan keterampilan setiap anggota kelompok. Pendapat diatas juga didukung oleh pendapat Isjoni (2011:77) yang mengatakan bahwa pembelajaran kooperatif Jigsaw merupakan salah satu tipe pembelajaran kooperatif yang mendorong peserta didik aktif 
dan saling membantu dalam menguasai materi pelajaran untuk mencapai prestasi yang maksimal. Jigsaw dalam penelitian ini menggunakan langkah pembelajaran yang dikemukakan Lie, A (Julianto, 2011:31) yang tahapan langkah meliputi menyampaikan tujuan dan memotivasi peserta didik, menyajikan informasi, kelompok dasar/asal atau base group, kelompok ahli atau expert group, tim ahli kembali ke kelompok dasar, evaluasi, dan pemberian penghargaan. Penggunaan model kooperatif tipe jigsaw ini dirasa tepat untuk meningkatkan keterampilan berbicara dan hasil belajar.

\section{Metode}

Penelitian mengenai penerapan model cooperative learning type jigsaw untuk meningkatkan keterampilan berbicara dan hasil belajar pembelajaran tematik kelas IV SD Negeri Noborejo 01 merupakan Penelitian Tindakan Kelas. Penelitian tindakan kelas adalah penelitian yang dilaksanakan di kelas yang tujuan utamanya adalah untuk memperbaiki kualitas pembelajaran.

Penelitian ini akan dilaksanakan di SD Negeri Noborejo 01 Kecamatan Argomulyo Kota Saltiga pada semester II tahun ajaran 2018/2019. Penelitian ini dilaksanakan pada bulan Maret semester II tahun ajaran 2018/2019.

Subjek penelitian ini adalah kelas IV SD Negeri Noborejo 01 Kecamatan Argomulyo Kota Saltiga yang berjumlah 34 peserta didk dengan peserta didik laki-laki berjumlah 18 peserta didik dan peserta didik perempuan berjumlah 16 . Obyek penelitian ini adalah pembelajaran tematik dengan menggunakan model cooperative learning type jigsaw.

Penelitian ini dilakukan dengan menggunakan pendekatan penelitian tindakan kelas (classroom action research). Adapun desain penelitian yang peneliti gunakan adalah desain Kemmis yang dikembangkan oleh Stephen Kemmis dan Robin Mc Taggart (Hamzah, 2011:87) dijelaskan bahwa di dalam satu siklus atau putaran terdiri dari empat komponen yaitu perencanaan (planning), tindakan (acting), observasi (observation), dan refleksi (reflection) dengan menjadikan satu kesatuan komponen tindakan (action) dan observasi (observation). Keempat prosedur tersebut harus dilakukan secara berurutan dan tidak boleh ada yang terlewatkan. desain penelitian tersebut adalah sebagai berikut: Stephen Kemmis dan Robin Mc Taggart (Hamzah, 2011:87) .

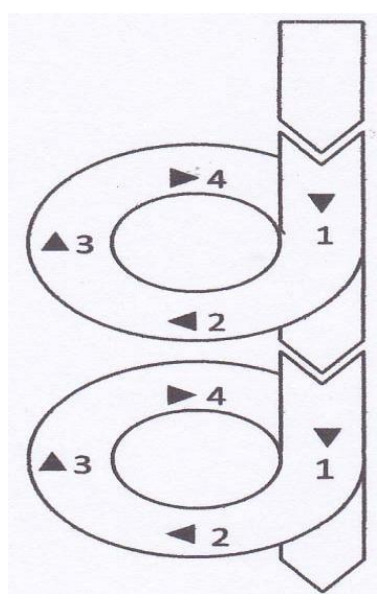

Gambar 1. Desain Penelitian

Analisis data yang digunakan dalam penelitian ini adalah dengan menelaah seluruh data yang tersedia dari berbagai sumber yaitu dari observasi, wawancara, studi dokumen, dan tes setiap siklus. Proses analisis data observasi, wawancara, dan studi dokumen dianalisis secara deskriptif untuk melengkapi data sehingga data peningkatan keterampilan berbicara dan hasil belajar peserta didik lebih akurat. Penelitian ini dianggap berhasil jika 80\% peserta didik kelas IV SD Negeri Noborejo 01 Kecamatan Argomulyo Kota Salatiga bisa mencapai KKM pembelajaran tematik, baik dalam keterampilan berbicara maupun dalam prestasi belajar. KKM 70 adalah standar minimalnya. Peneliti mendorong peningkatan keterampilan berbicara dan hasil belajar peserta didik dengan penerapan model cooperative learning type jigsaw. Dalam penelitian ini, peningkatan keterampilan berbicara dan hasil belajar peserta didik dianalisis dengan mencari nilai rata-rata. 


\section{Hasil dan Pembahasan}

Berdasarkan hasil penilaian siklus I dan siklus II menunjukkan peningkatan. Berikut ini perbadingan penilaian keterampilan berbicara peserta didik berdasarkan hasil penilaian siklus I dan siklus II.

Tabel 1. Perbandingan Tingkat Keterampilan Berbicara Siklus I dan Siklus II Peserta Didik SDN Noborejo 01 Tahun Ajaran 2018/2019.

\begin{tabular}{cccccc}
\hline & & \multicolumn{2}{c}{ Siklus 1 } & \multicolumn{2}{c}{ Siklus 2 } \\
\cline { 3 - 6 } No & Kategori & $\mathrm{F}$ & $\%$ & $\mathrm{~F}$ & $\%$ \\
\hline 1. & Tuntas & 10 & $29 \%$ & 14 & $41 \%$ \\
2. & Sedang & 14 & $41 \%$ & 16 & $47 \%$ \\
3. & Rendah & 4 & $18 \%$ & 2 & $6 \%$ \\
4. & Sangat Rendah & $40 \%$ & $12 \%$ & 2 & $6 \%$ \\
& Nilai Tertinggi & & & $96 \%$ & \\
& Nilai Terendah & $23 \%$ & & \multicolumn{2}{c}{$7 \% \%$} \\
\hline
\end{tabular}

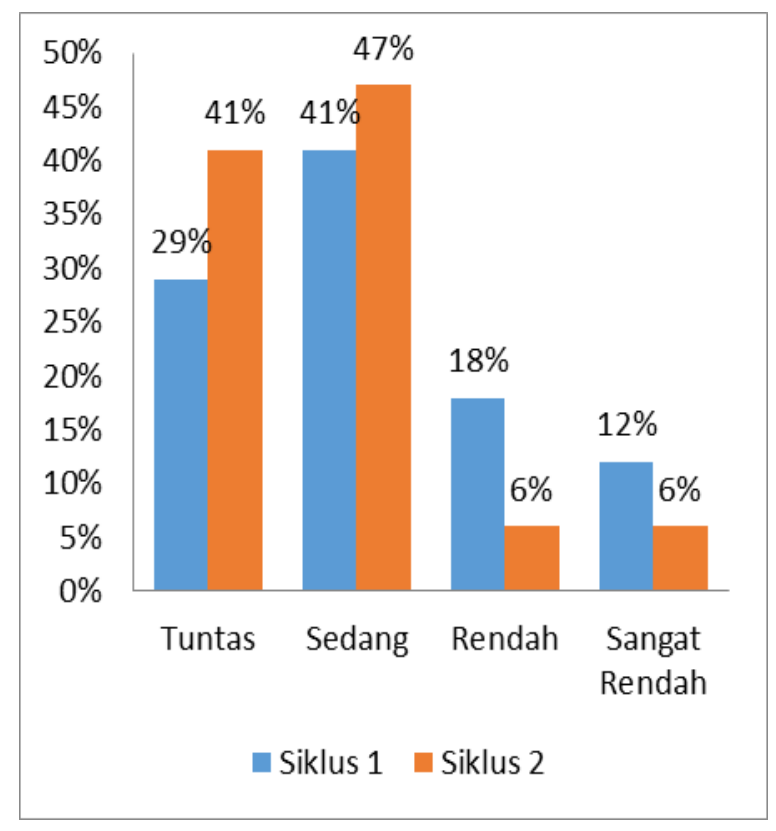

Grafik 1. Perbandingan Tingkat Keterampilan Berbicara Siklus I dan Siklus II Peserta Didik SDN Noborejo 01 Tahun Ajaran 2018/2019.

Berdasarkan tabel dan grafik hasil penelitian diatas, terdapat peningkatan siklus I ke siklus II kategori tuntas pada presentase siklus I sebesar 29\% (10) peserta didik meningkat presentase siklus II sebesar 41\% (14) peserta didik. Selanjutnya peningkatan pada kategori sedang pada presentase siklus I sebesar 41\% (14) peserta didik meningkat presentase siklus II sebesar 47\% (16) peserta didik. Kemudian pada kategori rendah mengalami penurunan dari presentase siklus I sebesar 18\% (6) peserta didik menurun presentase siklus II sebesar 6\% (2) peserta didik. Selanjutnya penurunan pada kategori sangat rendah pada presentase siklus I sebesar 12\% (4) peserta didik menurun presentase siklus II sebesar 6\% (2) peserta didik. Penurunan pada presentase rendah dan sangat rendah dari siklus I ke siklus II terjadi karena terjadi peningkatan pada kategori sedang dan tuntas, yang membuktikan peserta didik dari siklus I ke siklus II mengalami peningkatan kualifikasi yang lebih baik. Hal ini dibuktikan dengan presentase ratarata yang mengalami peningkatan sebesar 18\% dengan presentase rata-rata pada siklus I sebesar 55\% siklus II sebesar $73 \%$. 
Berdasarkan hasil belajar pra siklus, siklus I dan siklus II menunjukkan peningkatan. Berikut ini perbadingan hasil belajar peserta didik berdasarkan hasil belajar pra siklus, siklus I dan siklus II.

Tabel 2. Perbandingan Hasil Belajar Pra siklus, Siklus 1 dan Siklus 2 Peserta Didik SDN Noborejo 01 Tahun Ajaran 2018/2019.

\begin{tabular}{ccccc}
\hline & & \multicolumn{3}{c}{ Hasil Belajar } \\
\cline { 3 - 5 } No & Kategori & Pra siklus & Siklus I & Siklus II \\
\hline 1. & Tuntas & 22 & 24 & 30 \\
2. & Tidak Tuntas & 14 & 10 & 4 \\
& Nilai Tertinggi & 92 & 100 & 100 \\
& Nilai Terendah & 44 & 60 & 66 \\
& Rata-rata & 67 & 76 & 80 \\
\hline
\end{tabular}

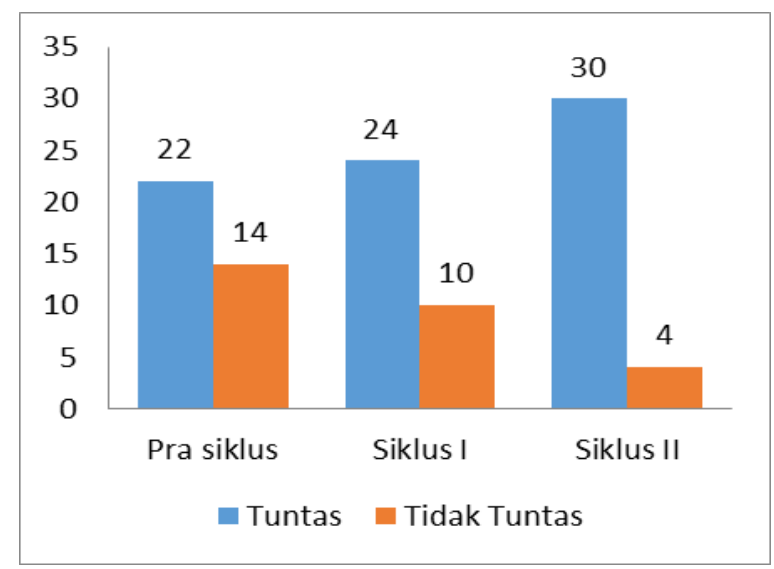

Grafik 2. Perbandingan Hasil Belajar Pra siklus, Siklus I dan Siklus II Peserta Didik SDN Noborejo 01 Tahun Ajaran 2018/2019.

Berdasarkan data yang disajikan pada tabel dan grafik di atas dapat dilihat bahwa hasil belajar peserta didik pada pembelajaran tema 6 "Cita-citaku" di kelas IV SD Negeri Noborejo 01 dari pra siklus , siklus I dan siklus II menunjukan peningkatan. Hal ini dapat ditunjukan pada pra siklus jumlah peserta didik yang telah mencapai ketuntasan (70) ada 22 peserta didik meningkat pada siklus I menjadi 24 peseta didik dan mengalami peningkatan yang lebih baik lagi pada siklus II menjadi 30 peserta didik. Dengan demikian, dapat dikatakan bahwa pada siklus II berhasil mencapai indikator kinerja yang ditentukan $80 \%$.

Materi pembelajaran yang dipakai di penelitian ini adalah tema 6 cita-citaku subtema 1 aku dan cita-citaku pembelajaran 3 dan tema 6 cita-citaku subtema 3 giat meraih cita-cita pembelajaran 3 yang juga disesuaikan agar dapat dilakukan sesuai dengan langkah-langkah dalam model pembelajaran kooperatif tipe Jigsaw. Penerapan model pembelajaran kooperatif tipe jigsaw untuk meningkatkan keterampilan berbicara dan hasil belajar pembelajaran tematik kelas IV SDN Noborejo 01 dilaksanakan dalam II siklus. Pada pelaksanaan siklus I berdasarkan lembar pengamatan menggunakan model kooperatif learning tipe jigsaw pada siklus I, hal yang dapat direflesksikan dalam penelitian siklus I diantaranya secara keseluruhan proses pembelajaran yang dilakukan oleh guru sudah sesuai dengan tahap model pembelajaran Kooperatif Learning Tipe Jigsaw dan berjalan dengan baik. Hal ini dapat dilihat dari lembar aktivitas guru menggunakan model pembelajaran Kooperatif Learning Tipe Jigsaw yang kegiatan sudah terlaksana, guru harus lebih fokus dan memperhatikan kegiatan diskusi kelompok peserta didik yang sedang mengerjakan lembar kerja kelompok agar setiap anggota dalam kelompok dapat berkerjasama dan menjalankan tugasnya, penguasaan kelas dalam mengamati kelompok yang beberapa anggota kelompok masih berbicara sendiri dan hanya beberapa peserta didik yang mengerjakan tugas kelompok perlu ditingkatkan, manajemen waktu peserta didik dalam menyelesaikan lembar kerja kelompok lebih diperhatikan dan lebih didorong agar semua kelompok dapat menyelesaikannya dengan 
waktu yang tepat, sebagian peserta didik kurang memperhatikan pada saat kelompok melakukan diskusi dan sebagian peserta didik masih malu-malu ketika membacakan puisi didepan kelas sehingga indikator keterampilan berbicara kurang terlaksana.

Pada pelaksanaan siklus II berdasarkan lembar pengamatan menggunakan model kooperatif learning tipe jigsaw pada siklus II, hal yang dapat direflesksikan dalam penelitian siklus II diantaranya berdasarkan lembar observasi aktivitas guru dan aktivitas peserta didik dalam menggunakan model Koopearatif Learning Tipe Jigsaw terjadi peningkatan yang lebih baik dalam proses pembelajaran dibuktikan dengan indikator keterlaksanaan yang lebih baik daripada siklus I. Guru dalam melaksanaan proses pembelajaran berjalan dengan baik, penguasaan kelas, merangsang interaksi peserta didik dan mengatur jalannya diskusi kelompok dengan baik, peserta didik berdiskusi dengan baik dengan kelompoknya, setelah guru membimbing peserta didik keterampilan berbicara peserta didik lebih berani dan percaya diri sehingga ketika membacakan puisi didepan kelas sudah baik dan indikator keterampilan berbicara terlaksana sehingga hasil belajar pun meningkat.

Berdasarkan hasil penelitian, penggunaan model pembelajaran kooperatif tipe Jigsaw ternyata dapat meningkatkan keterampilan berbicara siswa kelas IV SD Negeri Noborejo 01. Hal ini dikarenakan pembelajaran kooperatif tipe Jigsaw dapat melatih peserta didik untuk mengembangkan keterampilan berbicara yang dimiliki peserta didik. Hasil penelitian ini memperkuat penelitian terdahulu seperti yang dilakukan oleh Piasih, Ariyanti, dan Dantes (2013), penelitian milik Sumarno, dan Handayani (2014), Aminah (2017), Wardani (2013). Serta penelitian yang dilakukan oleh Utariasih (2017) yang menyatakan pembelajaran dengan menggunakan model pembelajaran kooperatif tipe jigsaw berbantuan media gambar berpengaruh terhadap hasil belajar IPA siswa kelas V SD di Gugus V Kecamatan Banjar tahun ajaran 2017/2018. Model pembelajaran kooperatif tipe Jigsaw selalu melatih peserta didik untuk dapat mengembangkan keterampilan berbicaranya karena dalam pembelajaran kooperatif tipe Jigsaw semua peserta didik mempunyai peluang yang sama dalam berbicara. Pembelajaran kooperatif tipe Jigsaw mampu mengaktifkan peserta didik untuk belajar meningkatkan keterampilan berbicara secara maksimal. Di dalam proses pembelajaran, tidak ada peserta didik yang hanya sebagai pendengar saja karena setiap peserta didik mempunyai tanggung jawab masing-masing. Penggunaan model pembelajaran kooperatif tipe Jigsaw dalam pembelajaran telah menunjukkan adanya peningkatan keterampilan berbicara dan hasil belajar peserta didik kelas IV SD Negeri Noborejo 01. Hal diatas dapat dilihat dari peningkatan keterampilan berbicara peserta didik yaitu nilai rata-rata kelas pada siklus I 55\% dan pada siklus II menjadi 73\%. Peningkatan hasil belajar peserta didik pada pra siklus 67 pada siklus I menjadi 76 dan pada siklus II meningkat menjadi 80. Berdasarkan uraian di atas, yang disesuaikan dengan pendapat para ahli dan hasil observasi, menunjukkan bahwa penggunaan model pembelajaran kooperatif tipe Jigsaw terbukti dapat meningkatkan keterampilan berbicara dan hasil belajar peserta didik.

\section{Simpulan Dan Saran}

Berdasarkan hasil penelitian dan pembahasan yang dilakukan dapat disimpulkan bahwa penerapan model Cooperatif Learning tipe Jigsaw dapat meningkatkan keterampilan berbicara dan hasil belajar pembelajaran tematik kelas IV SD Negeri 01 Noborejo semester II tahun pelajaran 2018/2019 hal itu ditunjukkan sebagai berikut:

Pada siklus I keterampilan berbicara peserta didik sebesar 70\% (24) peserta didik dalam kategori tuntas dan peserta didik sebesar 30\% (10) peserta didik dalam kategoti tidak tuntas. Setelah pelaksaan tindakan keterampilan berbicara peserta didik pada siklus II meningkat menjadi 88\% (30) peserta didik dalam kategori tuntas dan peserta didik sebesar 12\% (4) peserta didik dalam kategori tidak tuntas.

Pada pra siklus hasil belajar peserta didik dari 34 peserta didik, 65\% (22) peserta didik tuntas dengan rata-rata 67 . Setelah pelaksaan tindakan hasil belajar peserta didik pada siklus I meningkat menjadi $71 \%$ (24) peserta didik tuntas dengan rata-rata 76 dan pada siklus II hasil belajar peserta didik semakin meningkat menjadi 87\% (30) peserta didik tuntas dengan rata-rata 80.

Penerapan model Cooperatif Learning Tipe Jigsaw juga memberikan dampak positif pada pembelajaran tematik di kelas 4 SD Negeri 01 Noborejo, diantaranya peserta didik aktif melaksanakan tugas belajarnya, terlibat dalam pemecahan masalah, peserta didik berani dan percaya diri dalam bertanya ataupun menjawab pertanyaan guru serta peserta didik menjadi lebih memahami materi yang diajarkan dengan penemuan dan pencarian informasi bersama kelompok. Penelitian ini dianggap berhasil 
karena sudah mencapai indikator keberhasilan yaitu keterampilan berbicara $80 \%$ dari seluruh peserta didik kelas IV berada pada kategoti tuntas dan hasil belajar $80 \%$ dari seluruh peserta didik kelas IV SD Negeri Noborejo 01 mencapai KKM $\geq 70$.

Berdasarkan simpulan di atas, dapat disampaikan beberapa saran yaitu: 1. Bagi guru, dalam menerapkan model pembelajaran berbantuan media konkret pada proses pembelajaran dikelas perlu memahami langkah-langkah model pembelajaran inkuiri, serta memperhatikan: (a) Alokasi waktu diatur sebaik mungkin sehingga tiap tahapan pembelajaran dapat berlangsung secara optimal; (b) Pembagian kelompok harus benar-benar diperhatikan yakni secara heterogen berdasarkan jenis kelamin dan prestasi siswa; (c) Memberikan bimbingan individu dan kelompok secara merata; (d) Memahami sifat dan karakteristik anak, 2. Bagi siswa, siswa diharapkan berperan aktif dalam pembelajaran, memperhatikan penjelasan guru dan ikut terlibat dalam setiap kegiatan pembelajaran sehingga prestasi belajar akan meningkat serta diharapkan dapat berkerja secara mandiri maupun kelompok dan bertanggungjawab atas tugas yang diberikandan 3. Bagi Kepala Sekolah, diharapkan mengembangkan dan mengkaji lebih luas lagi model-model pembelajaran untuk mendukung proses belajar mengajar yang sesuai dengan kurikulum dan karakteristik anak meliputi sarana dan prasarana yang menunjang pembelajaran

\section{Daftar Rujukan}

Afriki, dkk. 2016. Buku Guru Tema 6 "Cita-citaku”. Buku Tematik Terpadu Kurikulum 2013 Revisi 2016. Kementrian Pendidikan dan Kebudayaan.

Afriki, dkk. 2016. Buku Peserta didik Tema 6 "Cita-citaku”. Buku Tematik Terpadu Kurikulum 2013 Revisi 2016. Kementrian Pendidikan dan Kebudayaan.

Aminah, H. S. (2017). Peningkatan Hasil Belajar IPA Melalui Model Kooperatif Tipe Jigsaw Berbantu Media Gambar Kelas IV SDN 04 Jambangan 2016/2017 (Doctoral dissertation, Program Studi Pendidikan Guru Sekolah Dasar FKIP-UKSW).

Dantes, Nyoman. (2013). Pengaruh Model Pembelajaran Kooperatif Tipe Jigsaw Terhadap Kemampuan Berpikir Kritis Dan Prestasi Belajar Siswa Dalam Pembelajaran IPS Pada Siswa Kelas IV SD Cipta Dharma Denpasar (Jurnal Pendidikan Dasar Ganesha).

Hanafi P, Jamaludin J, Hasdin H. (2016). Penerapan Model Pembelajaran Jigsaw Untuk Meningkatkan Hasil Belajar Ilmu Pengetahuan Sosial (IPS) Siswa Kelas V SD Inpres Salabenda Kecamatan Bunta Semester I Tahun Pelajaran 2013/2014. Jurnal Kreatif Tadulako Online, 4(11), 200-209.

Harli T, Istutik Z. (2017). Strategi Implementasi Model Pembelajaran Kooperatif Tipe Jigsaw Kelas IV SD Negeri Godean 01 semester II tahun pelajaran 2016/2017. 7(2).

Hendri Guntur Tarigan. 2013. Berbicara Sebagai Suatu Keterampilan Berbahasa. Bandung: CV. Angkasa.

Kementrian Nomor 21 Tahun 2016. Standar Isi Pendidikan Dasar dan Menengah Tahun 2016.

Lie, A. (2008). Cooperative Learning. Jakarta: PT. Gramedia.

Mau'izah. (2013). Peningkatan Hasil Belajar Siswa Melalui Model Pendekatan Kooperatif Tipe Jigsaw Pada Mata Pelajaran IPS Kelas IV di SD Inpres Sintuwu Tahun Pelajaran 2013/2014. Jurnal Kreatif Tadulako Online, 5(8), 1-22.

Mawardi, M. (2014). Pemberlakuan Kurikulum Sd/Mi Tahun 2013 Dan Implikasinya Terhadap Upaya Memperbaiki Proses Pembelajaran Melalui PTK. Scholariia: Jurnal Pendidikan dan Kebudayaan, $4(3), 107-212$.

Robert E,Slavin, (2005). Cooperative Learning: teori, riset, dan praktik. Bandung: Nusa Media.

Rochiati Wiriaatmaja. (2008). Metode Penelitian Tindakan Kelas. Bandung: PT Remaja Rosdakarya.

Setyawan Pujiono. 2013. Terampil Menulis: Cara Mudah dan Praktis dalam Menulis. Yogyakarta: Graha Ilmu. 
Slavin, R.E. 2009. Cooperative Learning. Bandung : Nusa Media.

Sumarno. Handayani, S. \& Triyono. (2013). Penerapan Model Pembelajaran Kooperatif Tipe Jigsaw Untuk Meningkatkan Penguasaan Konsep dan Keterampilan Berpikir Kritis Pada Mata Pelajarn IPA SD di kabupaten Blora. (Program Studi Sekolah Dasar Universitas Terbuka).

Utariasih, Luh Juli, I Nyoman Jampel, I Nyoman Murda. 2018. PENGARUH JIGSAW BERBANTUAN MEDIA GAMBAR TERHADAP HASIL BELAJAR IPA KELAS V DI SD GUGUS V. Indonesian Journal Of Educational Research and Review, Vol. 1 No. 2.

Wedari Nur Faiza. (2014). Penerapan Model Pembelajaran Kooperatif Tipe Jigsaw Tema Lingkungan Untuk Mengingkatkan Hasil Belajar Siswa Kelas II SDN Bulusidokare Tahun Pelajaran 2013/2014. 2(2).

Widiastini, Kusmariyatni, dan Arini. (2014). Keefektifan Model Pembelajaran Kooperatif Tipe Jigsaw Untuk Meningkatkan Hasil Belajar IPS Siswa Kelas V Negeri 1 Tejakula Semester I Tahun Pelajaran 2012-2013. Journal Mimbar PGSD Universitas Pendidikan Ganesha Jurusan PGSD, 2(1).

Yeni Masluchah. (2014). Penerapan Model Pembelajaran Kooperatif Tipe Jigsaw untuk Meningkatkan Hasil Belajar IPS Siswa Kelas IV SDN Pamotan 01 Porong Sidoarjo Tahun Pelajaran 2013/2014. 1(2) 